\title{
Primary intrahepatic obliterating cholangitis: a possible variant of 'sclerosing cholangitis'
}

\author{
P. S. BHATHAL ${ }^{1}$ AND L. W. POWELL 2 \\ From the Departments of Pathology and Medicine, University of Queensland, Brisbane, \\ Australia
}

SUMMARY A sclerosing cholangitis confined to the intrahepatic ducts occurred in a 64-year-old man with a clinical picture of prolonged cholestatic jaundice. Two laparotomies and an operative cholangiogram demonstrated a normal extrahepatic biliary tree. The most prominent histological feature in the liver biopsy was the replacement of medium-sized bile ducts by fibrous cords. Electron microscopic examination of the liver showed changes attributable to cholestasis and cholesterol clefts in dense bodies. Needle-like and curved membrane-bounded inclusions of an obscure nature were also observed in some of the dense bodies. It is suggested that this case, together with nine histologically similar cases which have been labelled in the literature as 'primary biliary cirrhosis', represents a subgroup of sclerosing cholangitis in which only the intrahepatic ducts are affected.

Primary sclerosing cholangitis is a disease of unknown cause in which there is a generalized inflammation of the larger bile ducts with fibrosis and stenosis (Schwartz and Dale, 1958; Holubitsky and McKenzie, 1964). It has been described in association with ulcerative colitis (Shields, 1957; Goldgraber and Kirsner, 1960; Holubitsky and McKenzie, 1964; Smith and Loe, 1965;Warren, Athanassiades, and Monge, 1966; Thorpe, Scheuer, and Sherlock, 1967a), with regional enteritis (Atkinson and Carroll, 1964), retroperitoneal fibrosis (Bartholomew, Cain, Woolner, Utz, and Ferris, 1963; Smith and Loe, 1965), Riedel's struma (Bartholomew et al, 1963) and 'pseudo tumour' of the orbit (Wenger, Gingrich, and Mendeloff, 1965). The disease always involves the extrahepatic bile ducts and may be confined to them. However, in some cases the intrahepatic bile ducts may be affected as well (Manesis and Sullivan, 1965; Warren et al, 1966; Thorpe et al, 1967b). Indeed, Thorpe et al (1967a) emphasized the variable involvement of ducts of all sizes and suggested that sclerosing cholangitis might be merely one component of a syndrome in which pericholangitis represents the intrahepatic lesion.

In this paper we report the occurrence of a sclerosing cholangitis confined to the intrahepatic biliary tree. To our knowledge sclerosing cholangitis localized to the intrahepatic biliary tree has been

\footnotetext{
${ }^{1}$ Present address: Department of Pathology, University of Melbourne. ${ }^{2}$ Requests for reprints to L.W.P., Department of Medicine, Royal Brisbane Hospital, Brisbane 4029, Australia.
}

reported only once before (Hellstrom and PerezStable, 1966), in a patient who had also retroperitoneal fibrosis and disseminated vasculitis.

\section{CASE HISTORY}

A 64-year-old male pensioner had been treated since 1959 for increasing bilateral oedema of the lower limbs which was attributed to venous obstruction. He had undergone bilateral inguinal herniorrhaphy on three occasions over the previous 30 years and had clinical evidence of hypogonadism. In 1964 the liver was noted to be enlarged $5 \mathrm{~cm}$ below the right costal margin but there was no evidence of congestive cardiac failure. In March 1965 he complained of exertional dyspnoea and chest pain suggestive of angina pectoris. The patient was obese, with a distended, but not tender, abdomen and gross chronic oedema of the lower limbs. Blood pressure was $190 / 110 \mathrm{~mm} \mathrm{Hg}$, the pulse $90 /$ minute and regular, the jugular venous pressure was not elevated, and the heart sounds were normal. All lower limb pulses were present. The liver was enlarged $6 \mathrm{~cm}$ below the right costal margin on inspiration and was very firm. No other abdominal masses were palpable. There was bilateral testicular atrophy. The patient's previous drug therapy consisted of digoxin, methychlorthiazide, glyceryl trinitrate, phenylbutazone, penicillin, aminophylline, and ephedrobarbitone. Investigations gave these results: haemoglobin $16.5 \mathrm{~g} / 100 \mathrm{ml}$, white cell count $8,600 / \mathrm{cmm}$, differential count normal, erythrocyte sedimentation rate (ESR) $3 \mathrm{~mm}$ in one hour; serum level values were for uric acid $11.5 \mathrm{mg} / 100 \mathrm{ml}$, blood urea $36 \mathrm{mg} / 100 \mathrm{ml}$, cholesterol $277 \mathrm{mg} / 100 \mathrm{ml}$, calcium $9.7 \mathrm{mg} / 100 \mathrm{ml}$, inorganic phosphate $3.8 \mathrm{mg} / 100 \mathrm{ml}$, and alkaline phos- 
phatase (SAP) $50.4 \mathrm{~K}-\mathrm{A}$ units $/ 100 \mathrm{ml}$. The urine showed no cells or casts and culture was sterile. There was no albuminuria. An electrocardiograph (ECG) was consistent with an old anteroseptal myocardial infarct. A chest radiograph showed a dilated and tortuous aorta and some left ventricular enlargement.

In September 1966 the patient complained of increasing exertional dyspnoea and generalized pruritus. The liver was palpable $9 \mathrm{~cm}$ below the right costal margin. The spleen was impalpable. Other physical signs were as noted previously. On this occasion the haemoglobin was $10 \cdot 2 \mathrm{~g} / 100 \mathrm{ml}$, white cell count $7,500 / \mathrm{cmm}$, the differential count was normal, and the red cells showed some hypochromia and microcytosis. However, no evidence of blood loss was detected. The ESR was $87 \mathrm{~mm}$ in one hour. Liver function tests at that time were: serum bilirubin $1.5 \mathrm{mg} / 100 \mathrm{ml}$, CCFT negative, thymol turbidity 3.0 units, SAP $136 \mathrm{~K}$-A units/100 ml, SGOT 105 Karmen units/100 $\mathrm{ml}$, and serum uric acid $4.6 \mathrm{mg} / 100 \mathrm{ml}$. An ECG showed no change from the previous tracing.

The patient was admitted in March 1967 because of increasing exertional dyspnoea, postural giddiness, and angina pectoris. The generalized pruritus had also increased in severity. Examination showed scleral icterus and mucosal pallor. The liver was enlarged $12 \mathrm{~cm}$ below the right costal margin and felt hard. There was no other clinical evidence of hepatic disease. The blood pressure was $120 / 85 \mathrm{~mm} \mathrm{Hg}$, the heart sounds were normal and the jugular venous pressure was not raised. On this admission the patient's haemoglobin was $5.6 \mathrm{~g} / 100 \mathrm{ml}$ and the red cells were markedly hypochromic and microcytic. The ESR was $7 \mathrm{~mm}$ per hour and the white cell count $6,700 / \mathrm{cmm}$ with a normal differential count. A barium meal showed a deformity of the duodenal cap with no abnormality in the stomach or oesophagus. Tests for occult blood in faeces were positive. Serum values included: bilirubin $2.9 \mathrm{mg} / 100 \mathrm{ml}$, thymol turbidity 1.5 units, CCFT negative, alkaline phosphatase $182 \mathrm{~K}-\mathrm{A}$ units $/ 100 \mathrm{ml}$, and normal electrolyte concentrations. The blood urea was $58 \mathrm{mg} / 100 \mathrm{ml}$. The test for antimitochondrial antibodies, characteristically positive in patients with primary biliary cirrhosis (Walker, Doniach, Roitt, and Sherlock, 1965; Doniach, Roitt, Walker, and Sherlock, 1966), was negative. Fibroscopic examination revealed no abnormality in the stomach. The patient was transfused with 1 litre of whole blood and there was a marked improvement in symptoms. On 4 May 1967, laparotomy was performed. The liver was enlarged $12 \mathrm{~cm}$ below the right costal margin; the right lobe was more enlarged than the left. The gallbladder, common bile
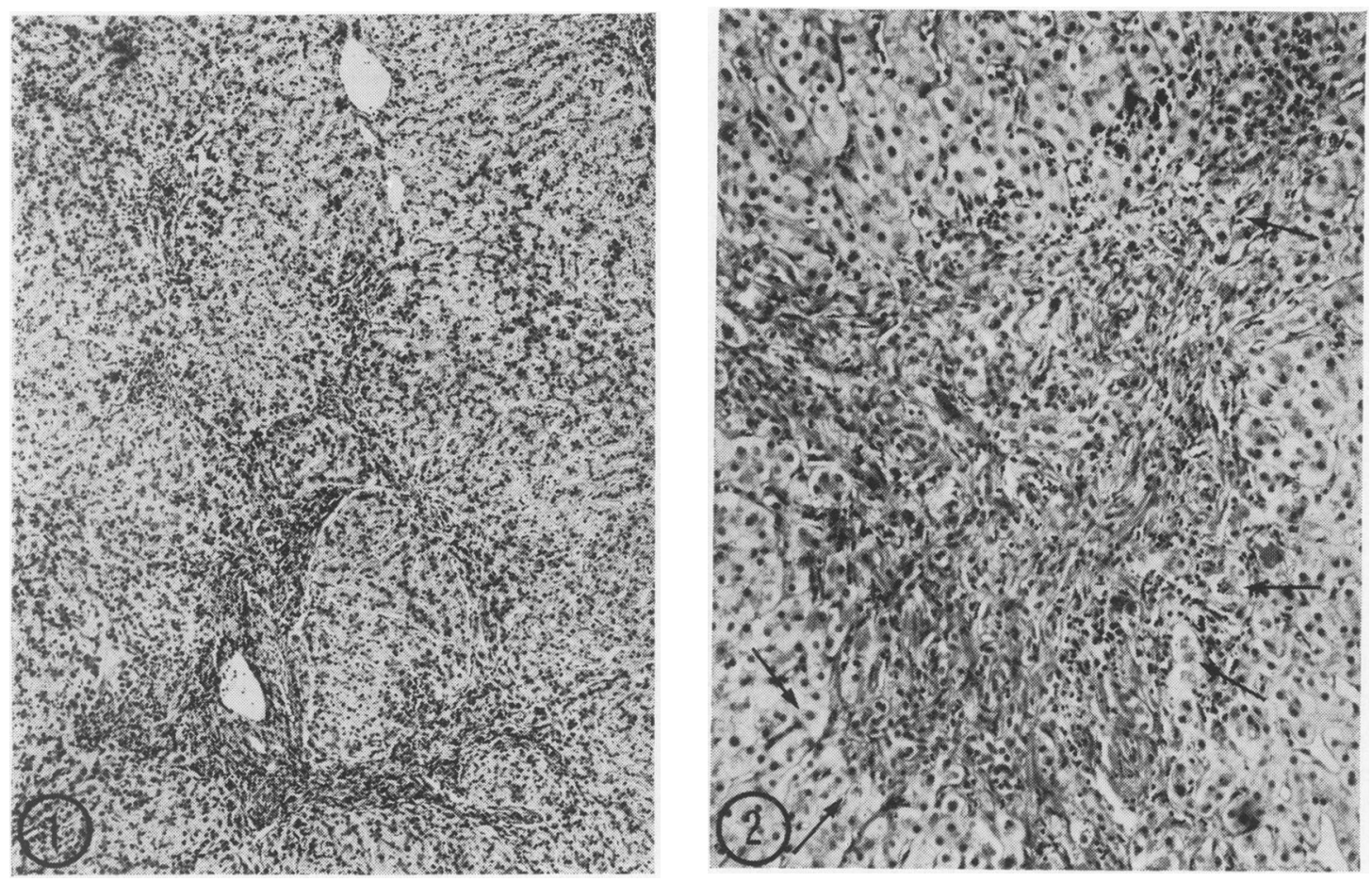

FIG. 1. Early distortion of liver architecture and piecemeal necrosis. Haematoxylin and eosin $\times 40$.

FIG. 2. Small portal tract showing fibrosis, bile ductule proliferation, and infiltration by inflammatory cells. Piecemeal necrosis and gro:ups of vacuolated liver cells (arrows) containing pigment and PAS-positive granules can be seen at the edges of the widened portal tract. PAS after digestion with diastase $\times 100$. 
duct, and other abdominal organs appeared normal. A wedge biopsy of the liver was taken together with a lymph node adjacent to the common bile duct. The latter showed evidence only of chronic, non-specific lymphadenitis on microscopic examination.

Histological examination of the liver showed a moderately distorted architecture. The portal tracts were widened and fibrous bands extended between adjacent portal tracts and occasionally connected portal tracts to central veins (Fig. 1). The central veins were generally intact. The limiting plate was broken by piecemeal necrosis of hepatocytes, and in some portal tracts fibrous tissue and condensed reticulin extended into the periportal parenchyma isolating liver cells (Fig, 2). The smaller portal tracts showed extensive bile ductule proliferation and a moderate to dense inflammatory infiltrate consisting of lymphocytes, neutrophils, and plasma cells (Fig. 2). Macrophages containing periodic acid-Schiff (PAS)-positive, diastase-resistant material were plentiful in some portal tracts. No granulomata were found. Some of the larger portal tracts contained lymphoid follicles. adjacent to ducts. One such follicle contained a secondary germinal centre (Fig. 3). The small and medium-sized ducts were all grossly abnormal due to concentric periductal fibrosis (Fig. 4). Many were represented by fibrous cords accompanying branches of the hepatic arteries and portal veins (Figs. 3, 4, and 5). Occasionally these scars were infiltrated by a few lymphocytes and plasma cells. Ducts lined by atypical epithelium (Rubin, Schaffner, and Popper, 1965; Williams, 1965) were not seen. The periportal parenchymal cells often possessed rarefied cytoplasm containing bile pigment (Fig. 2). One bile lake was found (Fig. 6). Periportal bile canaliculi were dilated and often contained bile thrombi.

A portion of the liver biopsy was fixed in $1 \%$ osmium tetroxide in Millonig's (1961) buffer and embedded in Epon for electron microscopy. Ultra-thin sections were doubly stained with uranyl acetate and lead hydroxide and examined in a Hitachi HS-7S electron microscope. These showed mainly cholestatic features. Dilated and normal-sized bile canaliculi were surrounded by a widened zone of pericanalicular ectoplasm and many dense bodies (Figs. 7 and 8). The dilated canaliculi were lined by fewer microvilli, some of which were oedematous (Fig. 8). Some canaliculi contained bile deposits. Some of the pericanalicular dense bodies contained stringy, coiled, strongly osmiophilic material while others showed flocculent or granular masses resembling bile pigment (Figs. 7 and 9). There were a few membrane-bounded composite bodies containing recognizable glycogen, ribosomes, lipid bodies, and deeply osmiophilic material. Some of these bodies also contained long needle-like and at times curved electron-lucent inclusions (Figs. 9 and 10). Others showed electron-lucent angular profiles resembling clefts left by dissolved cholesterol crystals (Fig. 11). Cholesterol clefts were occasionally found in bile duct cells. There were occasional areas of cytoplasmic degradation (Fig. 12) and occasional intracytoplasmic vacuoles with blebs of oedematous cytoplasm projecting into them (Fig. 13). Paracrystalline inclusions forming parallel arrays, when cut longitudinally, and a lattice-work pattern, in cross section, were found in the matrix of several mitochondria (Fig. 14).
On 9 May 1967 the serum bilirubin was $4.2 \mathrm{mg} / 100 \mathrm{ml}$, SAP $205 \mathrm{~K}-A$ units $/ 100 \mathrm{ml}$, and SGOT 67 Karmen units $/ 100 \mathrm{ml}$. Mean daily faecal fat excretion (over three consecutive days) was $11 \cdot 3 \mathrm{~g}$.

Over the next six months the patient remained jaundiced and although generalized pruritus was present it did not increase in severity. He was readmitted in March 1968 when laparotomy was again performed with exploration of the biliary tree. The findings were similar to those on the previous occasion except that the liver was slightly larger with nodules $1-2 \mathrm{~mm}$ in diameter causing the surface to appear granular. The common bile duct was normal in size and calibre (8 $\mathrm{mm}$ internal diameter). Operative cholangiograms showed normal common bile duct and main hepatic ducts but incomplete filling of the smaller intrahepatic ducts (Fig. 15). Contrast medium flowed freely into the duodenum. Biopsy of the liver showed changes similar to those described above. There was no evidence of retroperitoneal fibrosis or tumour. Relevant investigations at this time included; serum cholesterol $240 \mathrm{mg} / 100 \mathrm{ml}$, serum bilirubin 3.7 $\mathrm{mg} / 100 \mathrm{ml}$, SGOT $101 \mathrm{Karmen}$ units/100 ml, SAP 160 $\mathrm{K}-\mathrm{A}$ units $/ 100 \mathrm{ml}$, serum electrolytes normal, serum calcium $9 \cdot 1 \mathrm{mg} / 100 \mathrm{ml}$, phosphate $4.5 \mathrm{mg} / 100 \mathrm{ml}$, blood urea $33 \mathrm{mg} / 100 \mathrm{ml}$, serum total protein $7 \cdot 1 \mathrm{~g} / 100 \mathrm{ml}$, serum albumin $3.5 \mathrm{~g} / 100 \mathrm{ml}$, haemoglobin $11.8 \mathrm{~g} / 100 \mathrm{ml}$, leucocytes $6,500 / \mathrm{cmm}$, a normal differential count, and prothrombin time $100 \%$. Sigmoidoscopic examination revealed normal large bowel mucosa. A barium enema showed scattered diverticula in the lower descending colon but no radiological evidence of ulcerative colitis. On intravenous pyelography the renal shadows, collecting systems, and bladder were normal.

The patient's condition has since remained constant (Table). There has been no weight loss or recurrence of

TABLE

SUMMARY OF SERUM BIOCHEMICAL VALUES OVER FOUR YEARS

\begin{tabular}{|c|c|c|c|c|c|c|}
\hline & \multicolumn{6}{|c|}{ Date of Assay } \\
\hline & $\begin{array}{l}\text { March } \\
1965\end{array}$ & $\begin{array}{l}\text { Sept } \\
1966\end{array}$ & $\begin{array}{l}\text { May } \\
1967\end{array}$ & $\begin{array}{l}\text { Nov } \\
1967\end{array}$ & $\begin{array}{l}F e b \\
1968\end{array}$ & $\begin{array}{l}\text { April } \\
1969\end{array}$ \\
\hline $\begin{array}{l}\text { Bilirubin } \\
(\mathrm{mg} / 100 \mathrm{ml}) \\
\text { Alkaline phos- } \\
\text { phatase }(\mathrm{K}-\mathrm{A} \\
\text { units } / 100 \mathrm{ml})\end{array}$ & - & $1 \cdot 5$ & $4 \cdot 2$ & $6 \cdot 4$ & $4 \cdot 0$ & $4 \cdot 2$ \\
\hline $\begin{array}{l}\text { units/100 ml) } \\
\text { SGOT } \\
\text { (Karmen units) }\end{array}$ & $\begin{array}{l}50.4 \\
-\end{array}$ & $\begin{array}{l}136 \\
105\end{array}$ & $\begin{array}{r}205 \\
67\end{array}$ & $\begin{array}{l}190 \\
111\end{array}$ & $\begin{array}{l}160 \\
123\end{array}$ & $\begin{array}{l}165 \\
112\end{array}$ \\
\hline $\begin{array}{l}\text { Serum total } \\
\text { cholesterol } \\
\text { Serum total }\end{array}$ & 277 & 268 & - & 264 & 240 & 244 \\
\hline $\begin{array}{l}\text { proteins } \\
\text { Liver size } \\
\text { (cm below right }\end{array}$ & $\begin{array}{l}- \\
6 \\
\text { costal } n\end{array}$ & $\begin{array}{l}7 \cdot 6 \\
9 \\
\text { rgin) }\end{array}$ & $\begin{array}{l}6 \cdot 5 \\
12\end{array}$ & $12^{7 \cdot 6}$ & 12 & $12^{7 \cdot 6}$ \\
\hline
\end{tabular}

anaemia. He is constantly jaundiced with moderate generalized pruritus. The serum total bilirubin fluctuates between 3.0 and $6.5 \mathrm{mg} / 100 \mathrm{ml}$ and the SAP between 140 and $165 \mathrm{~K}-\mathrm{A}$ units $/ 100 \mathrm{ml}$.

\section{DISCUSSION}

The commonly accepted criteria for primary sclerosing cholangitis are: (1) diffuse inflammation 

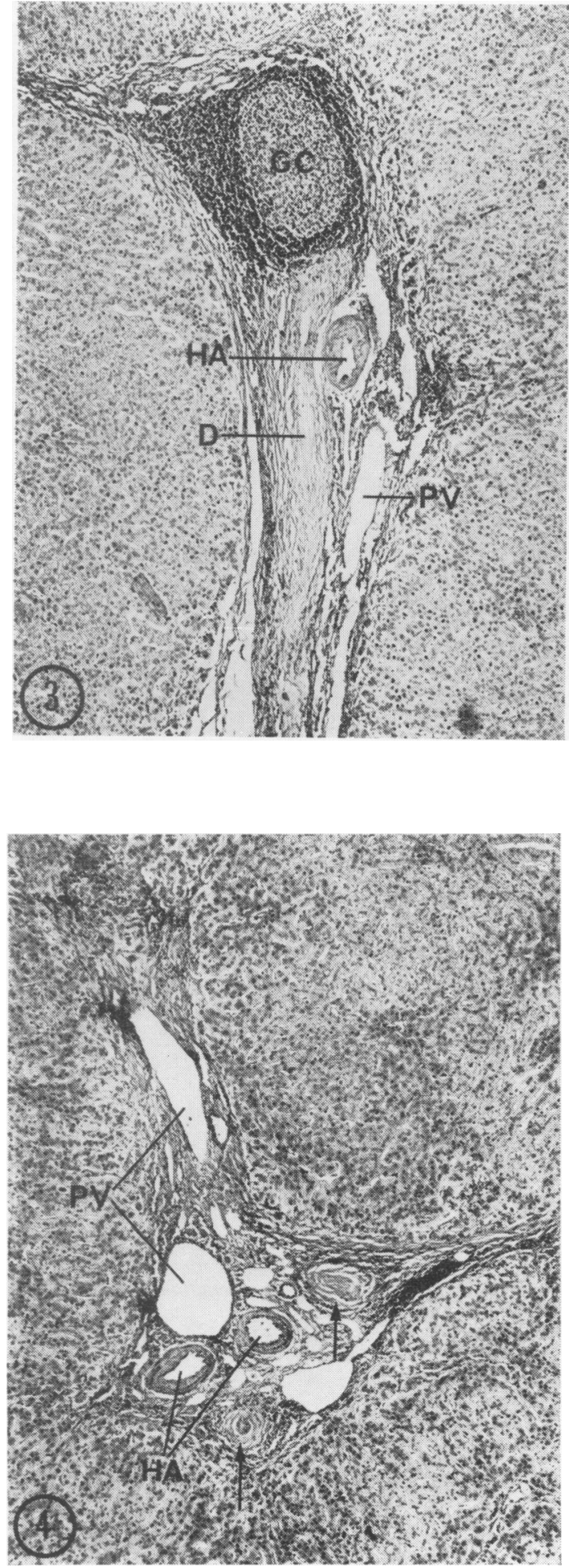

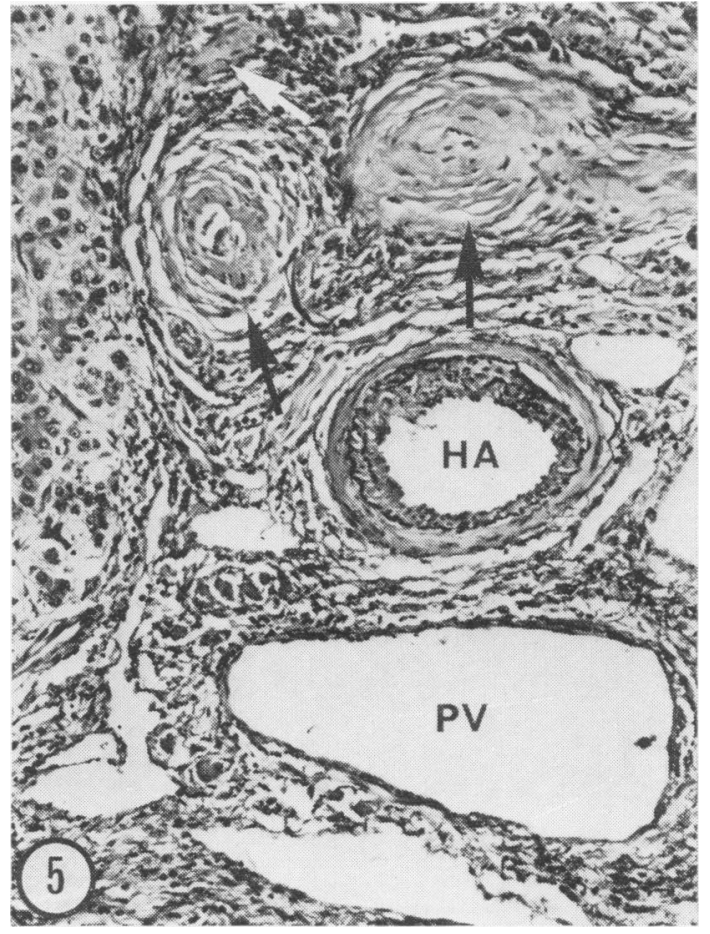

FIG. 3. Medium-sized portal tract containing branches of the hepatic artery $(H A)$ and portal vein $(P V)$ and a cordlike fibrous scar (D) replacing the interlobular duct. At one end of the portal tract is a lymphoid follicle containing a germinal centre $(G C)$. Haematoxylin and eosin $\times 40$.

FIG. 4. Portal tract containing a sclerosed interlobular duct (upper arrow) and an interlobular duct showing periductal fibrosis and narrowed lumen (lower arrow). $H A$, hepatic artery branches; $P V$, portal vein branches. Verhoeff Van Gieson $\times 40$.

FIG. 5. Two sclerosed interlobular ducts (black arrows) and one smaller scar (white arrow) can be seen. HA, branch of hepatic artery; $P V$, branch of portal vein. Verhoeff Van Gieson $\times 250$. 

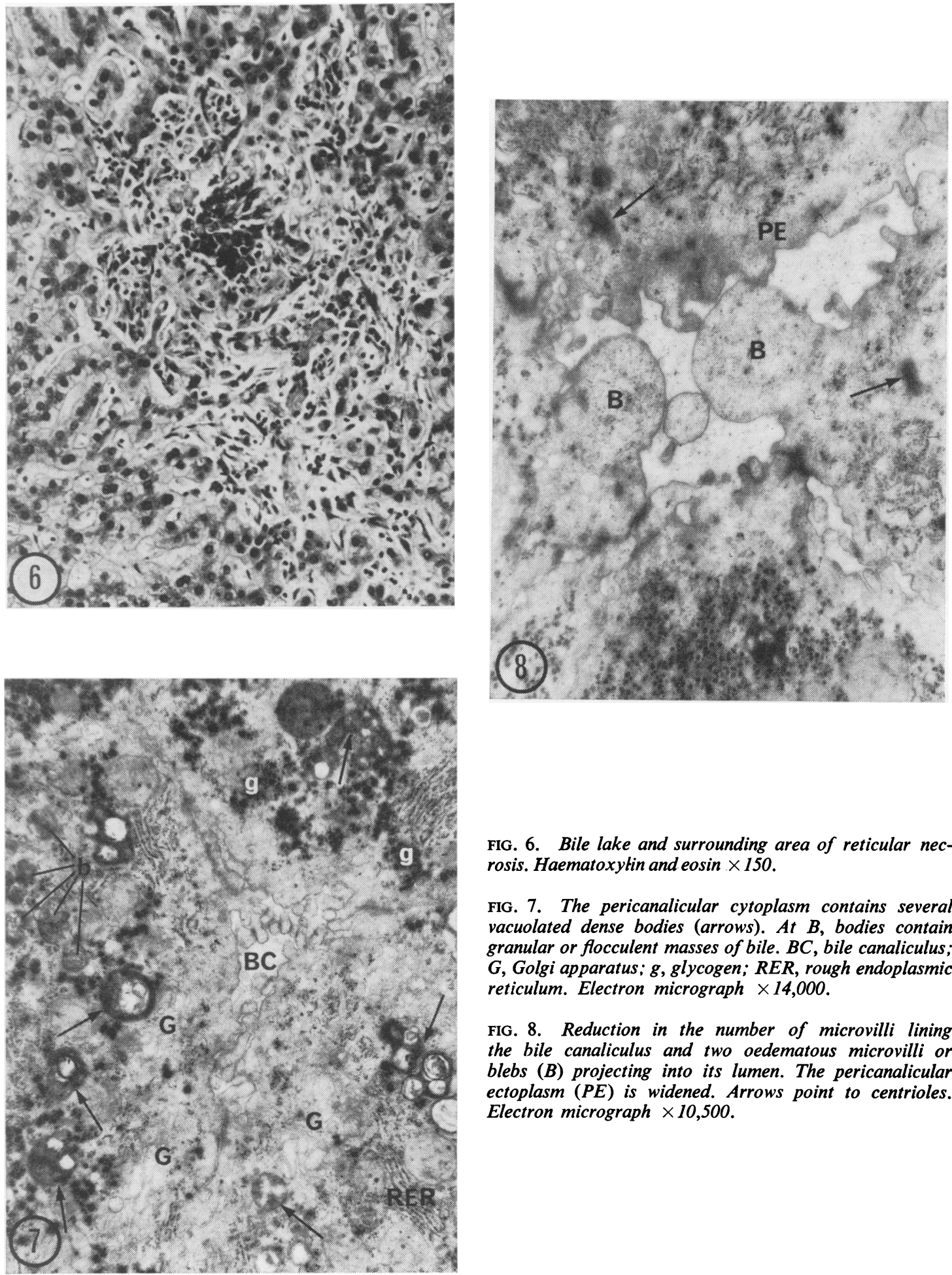

FIG. 6. Bile lake and surrounding area of reticular necrosis. Haematoxytin and eosin $\times 150$.

FIG. 7. The pericanalicular cytoplasm contains several vacuolated dense bodies (arrows). At B, bodies contain granular or flocculent masses of bile. BC, bile canaliculus; $G$, Golgi apparatus; $g$, glycogen; $R E R$, rough endoplasmic reticulum. Electron micrograph $\times 14,000$.

FIG. 8. Reduction in the number of microvilli lining the bile canaliculus and two oedematous microvilli or blebs (B) projecting into its lumen. The pericanalicular ectoplasm (PE) is widened. Arrows point to centrioles. Electron micrograph $\times 10,500$. 

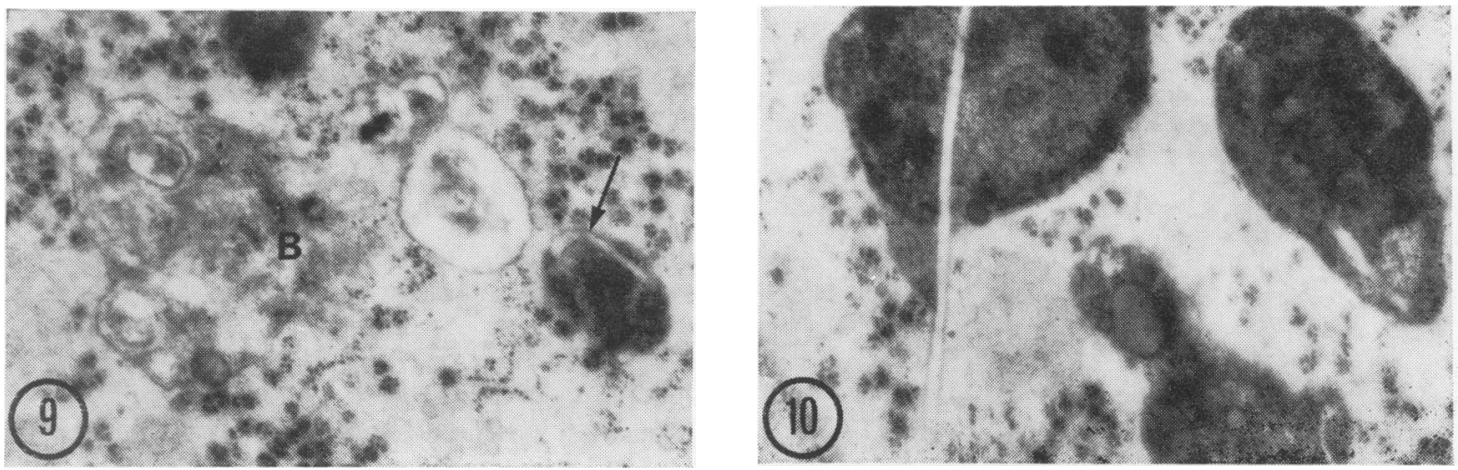

FIG. 9. Dense body containing a membrane-bounded electron-lucent inclusion (arrow). At B is an area of cytoplasm partly surrounded by a membrane. It contains vacuoles and flocculent material claimed by Biava (1965) to be bile. Electron micrograph $\times 20,000$.

FIG. 10. Three dense bodies containing electron-lucent inclusions, one of which is surrounded by a membrane and projects beyond the lysosome. Electron micrograph $\times 21,000$.
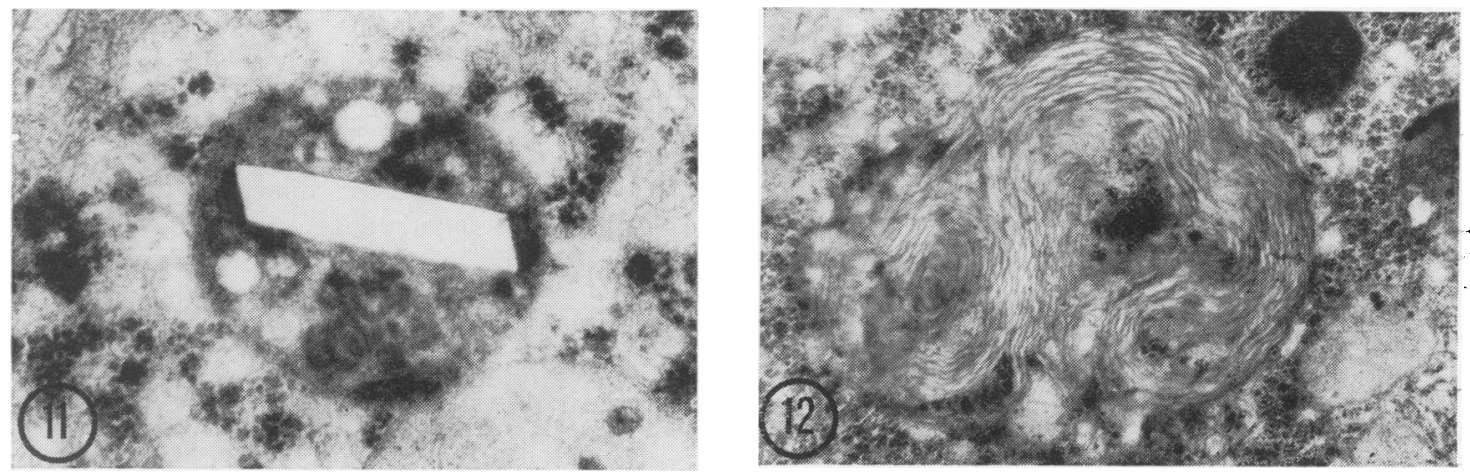

FIG. 11. A composite body containing a cleft produced by dissolved crystalline matter, vesicles, and deeply osmiophilic material. Electron micrograph $\times 41,000$.

FIG. 12. A myelin figure containing some glycogen particles within it. Electron micrograph $\times 16,000$.
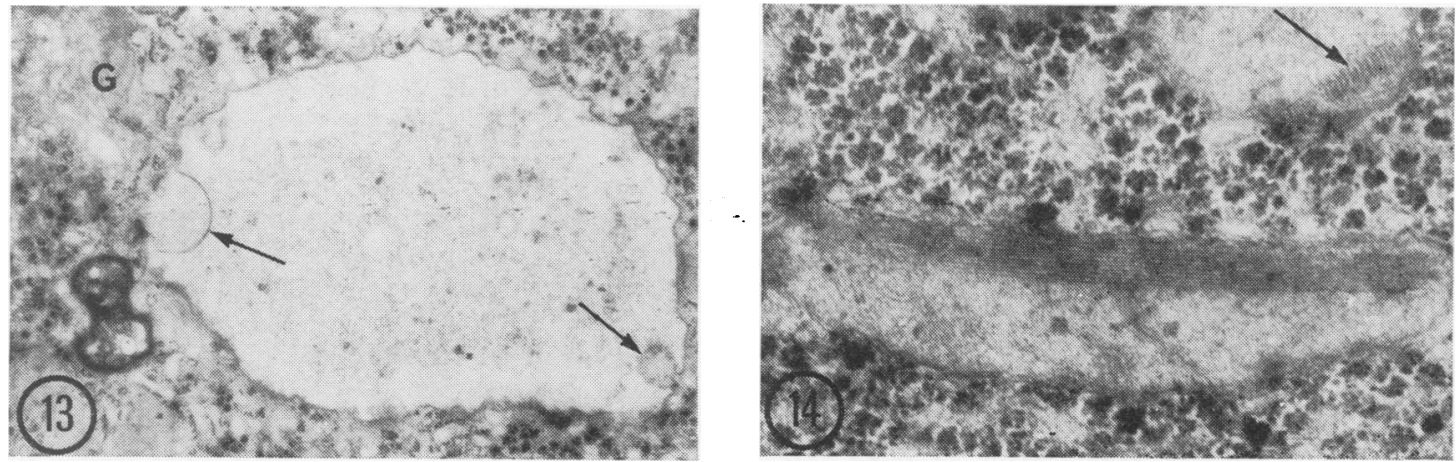

FIG. 13. An intracytoplasmic vacuole containing granular material and occasional vesicles. Two cytoplasmic mamillae (arrows) projects into it. G, golgi apparatus. Electron micrograph $\times 11,000$.

FIG. 14. Mitochondria, surrounded by glycogen, contain paracrystalline inclusions cut longitudinally and obliquely (arrow). Electron micrograph $\times 27,800$. 


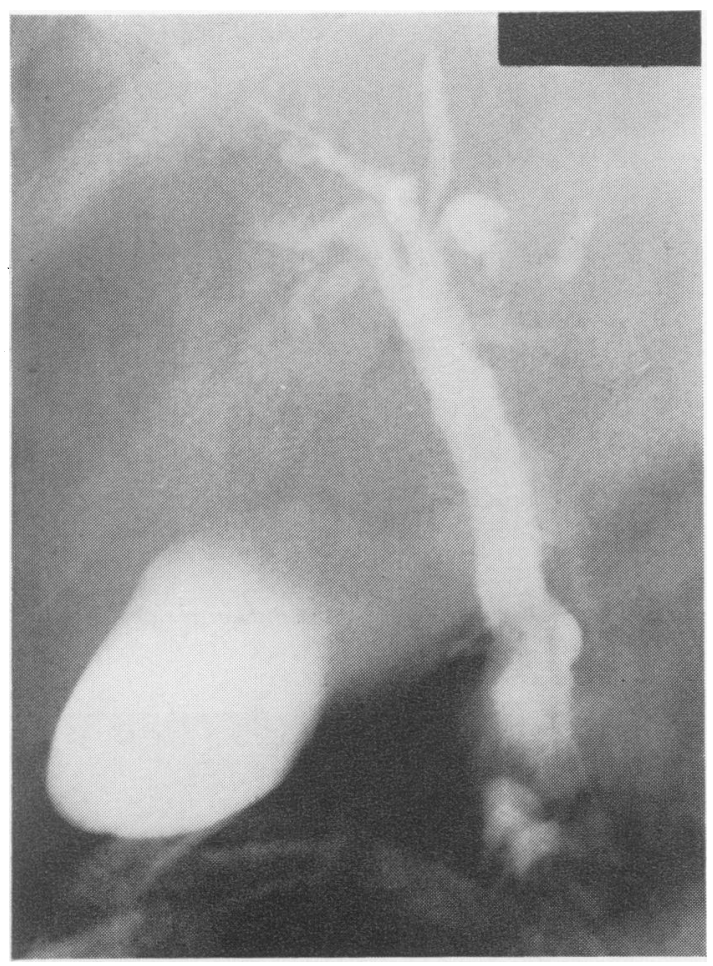

FIG. 15. Operative cholangiogram showing normal common bile duct and main hepatic ducts but incomplete filling of the smaller intrahepatic ducts. The surgeon has compressed the lower end of the common bile duct with his fingers as dye was flowing freely into the duodenum.

and fibrous thickening with concomitant narrowing of the whole or part of the extrahepatic biliary system; (2) absence of previous biliary tract surgery; (3) absence of calculous disease; and (4) exclusion of cholangio-carcinoma by reasonably long follow up (Holubitsky and McKenzie, 1964; Warren et al, 1966; Thorpe et al, 1967). In some cases the sclerosing process may affect the intrahepatic bile ducts together with the extrahepatic biliary system (Schwartz and Dale, 1958; Holubitsky and McKenzie, 1964; Warren et al, 1966; Thorpe et al, 1967). The only previous report of sclerosing cholangitis affecting solely the intrahepatic ducts appears to be that of Hellstrom and Perez-Stable (1966).

The most prominent histological feature in the present case was the replacement of most interlobular ducts by thick fibrous cords with complete obliteration of their lumina. Other ducts showed concentric periductal fibrosis. Occasional lymphoid follicles with germinal centres were found adjacent to some fibrotic ducts but no instance of septal or interlobular ducts completely surrounded by lymphoid follicles was found and periductal granulomata characteristically seen in primary biliary cirrhosis (Williams, 1965; and Rubin et al, 1965) were not seen. The pathological appearances did not really fit any of the three phases of primary biliary cirrhosis described by Rubin et al (1965) and the lesions of medium-sized bile ducts considered pathognomonic of that condition by Rubin et al (1965) and Williams (1965) were not seen. However, it is realized, as pointed out by the above authors, that the latter lesions may not be present in the terminal stages of the disease.

The histological appearances in the liver in the case reported by Klemperer (1937) as 'chronic intrahepatic obliterating cholangitis' exactly match the findings in the present case as judged by the description and illustrations offered by him. Replacement of intrahepatic bile ducts by fibrous cords has also been described by Moschowitz (1952) in two out of six cases of primary biliary cirrhosis. Rubin et al (1965) also mention the presence in portal tracts of scars that could have represented obliterated bile ducts in seven instances in 63 patients with primary biliary cirrhosis. However, fibrous, cord-like obliteration of intrahepatic ducts was not noted in the detailed histological studies of primary biliary cirrhosis in the 15 cases described by Ahrens, Payne, Kunkel, Eisenmenger, and Blondheim (1950), in 23 cases by Jones and Tisdale (1963), in 33 cases by Baggenstoss, Foulk, Butt, and Bahn (1964), in six cases by Williams (1965), and in 30 cases by Goudie, Macsween, and Goldberg (1966). Thus of the 176 cases of primary biliary cirrhosis recently reported, fibrous obliteration of the intrahepatic ducts was found in only nine instances.

We suggest, therefore, that the cases described by Klemperer (1937), Moschowitz (1952), Rubin et al (1965) and the present case, in which fibrous obliteration of intrahepatic ducts was a major feature, may represent intrahepatic sclerosing cholangitis as a distinctive entity. An alternative explanation is that it represents the end stage of primary biliary cirrhosis (chronic non-suppurative destructive cholangitis). The seven instances in which Rubin et al (1965) found scars representing obliterated ducts came from 17 specimens placed by them in the cirrhotic or type $\mathrm{C}$ stage of primary biliary cirrhosis in which the septa had smooth borders, hyalinized stroma, and contained few cells, ie, showed inactive cirrhosis. Our case showed only a mild degree of cirrhosis, the fibrous bands were often incomplete, and considerable activity in the form of piecemeal necrosis of liver cells and bile ductule proliferation was still present. Similarly, the description offered by 
Klemperer (1937) suggests considerable persistent activity.

Other points against the diagnosis of primary biliary cirrhosis in the present case are that the patient is an elderly male, the serum cholesterol level is normal, and the mitochondrial antibody test is negative. Non-organ-specific mitochondrial antibodies were found in $98 \%$ of patients with primary biliary cirrhosis by Doniach et al (1966), in $87 \%$ by Goudie et al (1966), and in $79 \%$ by Paronetto, Schaffner, and Popper (1967). The only paper reporting mitochondrial antibodies in primary sclerosing cholangitis is that of Thorpe et al (1967) who found weakly positive tests in two of their four cases. The fact that the patient's condition has remained fairly stationary and that it is now five years after the onset of the illness, together with the operative findings, makes the diagnosis of cholangiocarcinoma unlikely.

The ultrastructural changes are similar to those described by Klion and Schaffner (1966) in primary biliary cirrhosis. The angular crystalline profiles (Fig. 11) are regarded as spaces left after dissolution of cholesterol (Klion and Schaffner, 1966; Biava, 1965). However, the nature of the long needle-like and curved membrane-bounded inclusions seen in dense bodies in this study (Fig. 10) is obscure. Dilatation of bile canaliculi and the presence of oedematous microvilli within them, widening of the pericanalicular ectoplasm, hypertrophy of the Golgi apparatus, and retention of bile pigment within hepatocytic cytoplasm and bile canaliculi are signs of cholestasis, intra- and extrahepatic (Steiner, Jézéquel, Phillips, Miyai, and Arakawa, 1965). Intramitochondrial paracrystalline inclusions represent a non-specific change, having been described in viral hepatitis, acute and chronic alcoholism, amyloidosis, and even in 'normal' hepatocytes (Steiner et al, 1965).

We should like to thank Dr T. M. Ferrier for the opportunity of studying this case, and $\operatorname{Dr}$ A. F. Knyvett, Medical Superintendent of the Royal Brisbane Hospital, for permission to publish it.

The test for serum antimitochondrial antibodies was kindly performed by Dr Senga Whittingham, Melbourne.

\section{REFERENCES}

Ahrens, E. H., Jr., Payne, M. A., Kunkel, H. G., Eisenmenger, W. J., and Blondheim, S. H. (1950). Primary biliary cirrhosis. Medicine (Baltimore), 29, 299-364.

Atkinson, A. J., and Carroll, W. W. (1964). Sclerosing cholangitis. Association with regional enteritis. J. Amer. med. Ass., 188, 183-184.
Baggenstoss, A. H., Foulk, W. T., Butt, H. R., and Bahn, R. C. (1964). The pathology of primary biliary cirrhosis with emphasis on histogenesis. Amer. J. clin. Path., 42, 259-276.

Bartholomew, L. G., Cain, J. C., Woolner, L. B., Utz, D. C., and Ferris, D. O. (1963). Sclerosing cholangitis. Its possible association with Riedel's struma and fibrous retroperitonitisreport of two cases. New Engl. J. Med., 269, 8-12.

Biava, C. (1965). Electron microscopic studies on periodic acid-Schiffpositive nonglycogenic structures in human liver cells. Amer. J. Path., 46, 435-465.

Doniach, D., Roitt, I. M., Walker, J. G., and Sherlock, S. (1966) Tissue antibodies in primary biliary cirrhosis, active chronic (lupoid) hepatitis, cryptogenic cirrhosis and other liver diseases and their clinical implications. Clin. exp. Immunol., 1, 237-262.

Goldgraber, M. B., and Kirsner, J. B. (1960). Chronic granulomatous cholecystitis and chronic fibrosing choledochitis associated with chronic ulcerative colitis. A case report. Gastroenterology, 38, 821-828.

Goudie, R. B., Macsween, R. N. M., and Goldberg, D. M. (1966). Serological and histological diagnosis of primary biliary cirrhosis. J. clin. Path., 19, 527-538.

Hellstrom, H. R., and Perez-Stable, E. C. (1966). Retroperitoneal fibrosis with disseminated vasculit is and intrahepatic sclerosing cholangit is. Amer. J. Med., 40, 184-187.

Holubitsky, I. B., and McKenzie, A. D. (1964). Primary sclerosing cholangitis of the extrahepatic bile ducts. Canad. J. Surg., 7, 277-283.

Jones, W. A., and Tisdale, W. A. (1963). Posthepatitic cirrhosis clinically simulating extrahepatic biliary obstruction (so-called 'primary biliary cirrhosis'). New Engl. J. Med., 268, 629-639.

Klemperer, P. (1937). Chronic intrahepatic obliterating cholangitis. J. Mt Sinai Hosp., 4, 279-291.

Klion, F. M., and Schaffner, F. (1966). Electron microscopic observations in primary biliary cirrhosis. Arch. Path., 81, 152-161.

Manesis, J. G., and Sullivan, J. F. (1965). Primary sclerosing cholangitis. Arch. intern. Med., 115, 137-139.

Millonig, G. (1961). Advantages of a phosphate buffer for OsO. solutions in fixation. (Abstract.) J. appl. Phys., 32, 1637.

Moschowitz, E. (1952). Morphology and pathogenesis of biliary cirrhosis. Arch. Path., 54, 259-275.

Paronetto, F., Schaffner, F., and Popper, H. (1967). Antibodies to cytoplasmic antigens in primary biliary cirrhosis and chronic active hepatitis. J. Lab. clin. Med., 69, 979-988.

Rubin, E., Schaffner, F., and Popper, H. (1965). Primary biliary cirrhosis: chronic non-suppurative destructive cholangitis. Amer. J. Path., 46, 387-407.

Schwartz, S. I., and Dale, W. A. (1958). Primary sclerosing cholangit is. Arch. Surg., 77, 439-451.

Shields, A. B. (1957). Concurrent idiopathic obliterative cholangitis and ulcerative colit is. Portl. Clin. Bull., 2, 1-8.

Smith, M. P., and Loe, R. H. (1965). Sclerosing cholangitis : review of recent case reports and associated diseases and four new cases. Amer. J. Surg., 110, 239-246.

Steiner, J. W., Jézéquel, A-M., Phillips, M. J., Miyai, K., and Arakawa, K. (1965). Some aspects of the ultrastructural pathology of the liver. In Progress in Liver Diseases, edited by H. Popper, and F. Schaffner, vol. II, pp. 303-372. Grune and Stratton, New York.

Thorpe, M. E. C., Scheuer, P. J., and Sherlock, S. (1967). Primary sclerosing cholangitis, the biliary tree, and ulcerative colitis. Gut, 8, 435-448.

Walker, J. G., Doniach, D., Roitt, I. M., and Sherlock, S. (1965). Serological tests in diagnosis of primary biliary cirrhosis. Lancet, 1, 827-831.

Warren, K. W., Athanassiades, S., and Monge, J. I. (1966). Primary sclerosing cholangitis. A study of forty-two cases. Amer. J. Surg., 111, 23-38.

Wenger, J., Gingrich, G. W., and Mendeloff, J. (1965). Sclerosing cholangitis-a manifestation of systemic disease. Increased serum gamma-globulin, follicular lymph node hyperplasia, and orbital pseudotumour. Arch. intern. Med, 116, 509-514.

Williams, G. E. G. (1965). Pericholangiolitic biliary cirrhosis. J. Puth. Bact., 89, 23-34. 